The development of speaking fluency: The 4/3/2 technique for the EFL learners in China

Yang, Yingjie $\measuredangle$

University of Southern Queensland, Australia (U1040470@umail.usq.edu.au)

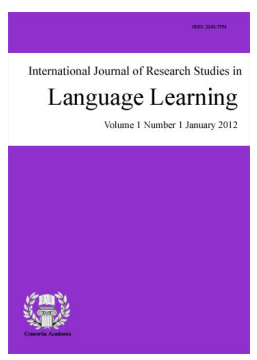

ISSN: 2243-7754 Online ISSN: 2243-7762

OPEN ACCESS

\title{
Abstract
}

EFL teaching is gradually changed from a traditional grammar-based model to a communicative language teaching approach in China. So, there is a variety of methodologies to help the Chinese EFL learners to practice their speaking skills. Lack of speaking fluency practice, sometimes, is not sufficient to maintain a communicative task in EFL class. This paper examines previous studies and researches in fluency development: to point out the importance of speaking fluency; to outline a 4/3/2 method adapting in the EFL class; to implement retrieval strategy to cultivate a long-term practice and to prove the fluency improvements in class will be beneficial in real-life conversation.

Keywords: EFL speaking, fluency development, the 4/3/2 activity, retrieval strategy, communicative language teaching 


\section{The development of speaking fluency: The 4/3/2 technique for the EFL learners in China}

\section{Introduction}

The EFL students are usually informed with the fluency achievement in a formal English language proficiency test. Such test result indicates their speaking proficiency level and also provides feedback on how to improve the speaking skill. The term 'fluency' was almost ignored throughout the traditional EFL leaning way in China since there is a lack of speaking activities for practicing fluency in class, less curriculum and syllabus supporting, or no instructed procedure for guiding the fluency development. However, the traditional grammar-based learning model is now steadily replaced by the communicative language teaching approach, which requires a strong speaking competence. The current EFL teaching attempts to improve learners' speaking fluency because of the communicative purpose in conversation. In this situation, it is necessary to pay attention on speaking fluency in a language course.

This paper critically discusses the importance of speaking fluency and identifies the speaking fluency development: to explore and state the main problems available in the EFL class in China and to seek the relevant solutions. There is a literature review of developing fluency with several previous researches. Some of these theories were proved by time and others alternatively are addressed to the further concerns in the EFL class. This article mainly applies a 4/3/2 technique to guarantee the ideal plan is implemented, to collect the statistical data and to monitor the progress of speaking fluency achievement throughout the fieldwork, and finally to suggest how speaking fluency can be promoted in an effective way. The practice of speaking fluency in a long-term period is a challenging task for both EFL teachers and learners, but also a powerful retrieval strategy to enhance the speaking competence in order to maintain the conversations in real life.

\section{Background of the Research Problem}

\subsection{The Spread of English Language}

The English language is widely recognized as an international language since it is an effective tool for the communication between different countries. Within the past few centuries, globalization indeed enables English spread everywhere in the world. Kachru (1992) pointed out that English was originally from the inner cycle: US, Canada, UK, Australia and New Zealand to the outer cycle there English is a Second Language including Malaysia, Kenya, Ghana and Singapore. However, there is an expanding cycle where English is taught as a Foreign Language in China, Japan and Korea. Nunan (2003) thought this trend of spread causes significant impact on the language policy, education system and language usage in many Asia countries. In 2001, the Chinese Ministry of Education announced and implemented a language policy: EFL teaching from grade 3 in all primary schools to the tertiary levels is compulsory. Besides, the Chinese-English bilingual education was encouraged in the tertiary institutions with $5 \%$ to $10 \%$ of the total courses. To sum up, students in China have to put their efforts in learning English.

\subsection{A Large Number of EFL Learners}

The spread of English, the promotion of English education and the communicative purpose, these lead to a large number of EFL learners in China. The statistical figure by An and Wang (2013) indicated that there are approximate 100 and 87 million of primary and secondary school learners plus 22 million tertiary students in China. Dai (2007) suggested this estimated figure may exceed 300 million, because the EFL trainees in other language schools and institutions should be calculated as well. More seriously, this number is still growing up dramatically in China. Gai (2004) analyzed there are many reasons for the Chinese EFL learners to invest time 
The development of speaking fluency: The 4/3/2 technique for the EFL learners in China

and money on learning English. The most important one is the communicative purpose is a motivational factor, because a good English speaker nowadays will have more competitive advantages to gain education opportunities overseas and have a good pathway in the career development. To conclude, these Chinese students are willing to learn English and improve their speaking skills.

\subsection{Constraints on Curriculum and Assessment}

There are many constraints on the EFL curriculum and syllabuses. Firstly, the curriculum design is still exam-driven. Learning in class contributes a lot for the examination instead of the real application. The CET level 4 and 6 in China requires the EFL students to process a lot of paper work but with a slight portion on assessing speaking. Such assessment will influence students' motivation in learning. Secondly, the unbalanced Chinese economy decides the difference in education funding and resources from the rich regions to the poor areas. Those rich places can recruit native EFL teachers whereas many EFL teachers in some poor areas are not professionally trained who rely on the grammar translation method, which is lack of theory support in the real practice (Richards \& Rodgers, 2001). A further challenge is that how the teacher assesses a big size class with 40 to 60 students. However, speaking fluency can be practiced in the communicative activities, which require all students participating in it. For example, the 4/3/2 activity (Maurice, 1983) is a good technique to cover a large class and students can listen and speak simultaneously. On the other hand, teachers should have a sense that grammar is not the first priority. Nation (1997) suggested that fluency development is an important component in EFL learning with one quarter of the class time. After all, students should believe that speaking fluently is achievable with their efforts.

\subsection{Proficiency Requirement}

Speaking fluently is one of the assessing criteria in many international language tests, for instance, IELTS and TOEFL assessing fluency in speaking session. Candidates cannot award a high overall score if grammar correct only, but not fluent in the test. The EFL teachers have responsibilities to teach their students' knowledge, in addition to help them to use the known content more fluently. However, a slow speed talking or a hesitant style passing the message is an obstacle in the communication. Speaking naturally and fluently is a challenge from memorizing language knowledge to using language to solve problems in the conversation. This is the goal to maintain the communication effectively, even though the definition of fluency is not agreed yet (Chambers, 1997). This clearly reveals the importance of speaking fluently in the EFL class in China. This proposed research not only supports the EFL learners to pass a proficiency test, but also provides the opportunity to extend the study of fluency development with the following questions.

\section{Statement the Researching Question}

Three questions will be addressed in this proposed research. They are contemporary questions in EFL field and logically internal related. Question one and two are widely discussed by many scholars. Nation (2007) stated the importance of speaking fluency and suggested many techniques for improving fluency. Some of the theories and previous findings will be proved in the fieldwork below. Question three will be answered by a mixed method with qualitative and quantitative methods.

\subsection{Addressing Questions}

$>\quad$ Question 1 - Why speaking fluently is so important for the EFL learners in China?

$>$ Question 2 - How to improve speaking fluency through the communicative activities in an environment that English is a Foreign Language?

$>\quad$ Question 3 - Whether the speaking fluency achievement in the practice task in class will support the real conversations that require similar languages and contents? 
Fluency - Fillmore (1979) defined fluency is the ability to talk at length with few pauses. A speaker is able to express his or her idea in a coherent way and to deal with lexical and syntactic items at a fast speed. Brumfit (1984) treated fluency as natural language use like the native speakers.

Accuracy - Accuracy is about the output and production matching the standards of a language. By contrast, many EFL teachers strongly believe that the more of an EFL learner's performance closing to the native speaker's performance, the more accuracy level the EFL learner achieves.

Communicative Language Teaching - The original consideration for the purpose of a language is interaction and communicated. At present, the communicative language teaching is a very popular method in language teaching (Richards \& Rodgers, 2001). The goal is driven by developing communicative competence.

Motivation - It is a desire involved in learning a language (Gardner, 1985). However, motivation is referred to the EFL learners' willingness of participation in the fluency activities in this research.

\section{Literature Review}

The term 'fluency' is widely used in language pedagogy and 'fluent' is regularly appeared in language testing and assessment. That seems the meaning of fluency is easily understood, however the definition of fluency is various. Hartmann and Stork (1976) pointed out 'fluent' means a speaker is able to use the correct structures of a language at normal speed, which means speaking naturally meanwhile concentrating on the content delivery rather than the form or structure of a language. Fillmore (1979) defined four abilities of speaking fluently: a) the ability to talk at length with few pauses; b) be able to produce the sentences coherently, reasoned and semantically; c) have appropriate expressions in a wide range of contexts; d) be creative and imaginative in language use. Nation (1989) provided three aspects of fluency: the first one is the speed and flow of language production; secondly, the degree of control of language items i.e. pausing, rhythm, pronunciation and stress; and the way of content interrupting is the last one. So far, the definition of fluency is developed into two main categories. One is called the narrow approach (Lennon, 2000) refers to the speaking speed and smoothness of the language delivery. The other is the board approach (Kopenen \& Riggenback, 2000) that considers a wider area including semantic density, appropriateness of expression, the language user's creative ability and some further issues in sociolinguistics.

Neither defining the term fluency is easy, nor the measure of fluency. To establish the standards of fluency is a complicate task, because fluency is totally a performance with the listener's impression and feeling. Lennon (1990) argued that fluency is not inviting the listener to pay attention on production of speaking, but the listener's attention on speaker's delivered message. This is the reflection of speaker's oral ability. Consequently, many researches attempted to identify the longitudinal fluency development (Towell, 1987; Lennon, 1990; Freed, 1995), to distinguish the fluent and non-fluent language learners (Riggenbach, 1991; Ejzenberg, 2000) and the fluency improvement in learning a language (Arevart \& Nation, 1991). Most of these researchers analyzed the amount of words articulated per minute and the average pause between different syllables in speaking. So, Wood (2001) summarized speech rate is an indicator of measuring fluency as speech rate shows the overall fluency of speaking. In many empirical studies, the phenomena of pause and pause filler are considered: the presence of filled and non-filled pauses in speaking of four English learners from China (Riggenbach, 1991) and the changes in the pause time of four German students (Lennon, 1990). To sum up, the definition and the measurement of fluency show the importance of developing fluency in EFL class.

There are some further studies on improving and developing fluency. Schloff and Yudkin's (1991) sixty second strategy advised learners with a slow speaking speed to choose a context about 180 words to read it loudly and practice for many times. Then, learners are encouraged to achieve a goal of finishing the reciting content in one minute without losing the original meanings. Fluency is directly associated with speed in this 
circumstance. Porter and Grant (1992) argued the EFL learners should not be trained by speeding up with sacrificing meaning and therefore to make the conversation difficult for understanding. Schneider (2001) proposed the pair-taping to encourage the EFL learners to interact in class due to the few opportunities of speaking English. Brenham and Stoops (1996) further suggested talking zone, speaking line and conversation game to face the challenge of L1 use in class. The over use of L1 may impact on the quality of lesson. In summary, all these proposed activities above create an opportunity for practicing the speaking fluency in the EFL class.

Before answering the question how to improve speaking fluency, it is necessary to draw attention on the function of fluency development. Is fluency development is a meaning-focused or form- focused task? According to Nation (2007), fluency development is a meaning-focused strand. Fluency strand exists if the EFL learners are familiar with the content; the focus is on processing the meaning; and there is some pressure to push the performance at a fast speed. Fluency or accuracy, meaning or form is widely debated. The best way is to merge them into different sequences. Nation's (2007) four strands successfully classified language learning through listening and reading is called meaning-focused input, whereas speaking and writing refer to meaning-focused output and form-focused instruction is focused on learning language features. The fourth strand is fluency development and they equally share one quarter of the class time. The EFL learners should put 25\% time and effort on fluency development. Arevart and Nation (1991) indicated the participants involved in the $4 / 3 / 2$ activity are more coherence in speaking in terms of the articulating words per minute increasing dramatically. Nation (1997) further found that speaking fluency development will improve the grammar accuracy, which is an additional contribution to the development of speaking fluency.

\section{Research Method}

The literature review builds up some fundamental theories for doing this research. The importance of speaking fluency is examined. The next concern is about how to improve speaking fluency through communicative activities in an environment that English is a Foreign Language. The research paradigm is on the basis of interpretivism. Scotland (2012) claims the interpretive epistemology is subjective and on the foundation of real phenomena. Any knowledge derived from such a research is consequently not possible to make any objective claim, by contrast to encourage the researcher subjectively to participate in the construction of knowledge. The implementation of the $4 / 3 / 2$ activity is a qualitative approach to prove its usefulness in the EFL class in China.

\subsection{Participants}

There are more than fifty EFL students in an observed class. These learners are undergraduate year one students from a rural university in China. Most of them have a good grammar background, some basic language knowledge and rich vocabulary, but they are lack of speaking practice. This research is narrowed into eleven participants. Geertz (1973) defined case study is a way to do observations and collect data in order to study a particular social phenomenon. A good case study is not just a good description, but also a sufficient solution. The class size is extreme large and the speaking opportunity is few in this circumstance. They indeed cherish the fluency practice in the $4 / 3 / 2$ activity. Motivation in this communicative task can help them to improve their speaking competence more effectively.

\subsection{Procedure}

The research procedure is about three months and the $4 / 3 / 2$ activity is used every week during the semester. Yin (2009) suggested the procedure of processing a case study is with four steps: designing, conducting, developing conclusion and providing relevant solution. A suggested procedure of running the 4/3/2 activity is presented below and then repeated every week by different topics and contents. Conclusion will be released by the end of semester in terms of proving the effectiveness and success of the previous studies. The solution to 
overcome the real conversation problem is the retrieval practice of the similar languages and contents in class. It is a long procedure and needs patience in doing so.

\subsection{Conditions and Guidelines}

\begin{tabular}{|l|l|}
\hline \multicolumn{1}{|c|}{ Conditions and Guidelines } & \multicolumn{1}{c|}{ Rationale } \\
\hline \multicolumn{1}{|c|}{$\begin{array}{l}\text { Learners must be familiar with content and } \\
\text { totally understand the content and language items. } \\
\text { That means no new language items and content; } \\
\text { Comprising meaning-focused activities that } \\
\begin{array}{l}\text { means it is possible for learners to make some } \\
\text { mistakes; }\end{array}\end{array}$} & $\begin{array}{l}\text { Nation (1989) mentioned the 4/3/2 activity } \\
\text { has three key features and they are repetition, } \\
\text { reducing time and a change of audience. }\end{array}$ \\
At least six students and there is no maximum; & $\begin{array}{l}\text { Arevart and Nation (1991) pointed out that } \\
\text { the reduced time gives pressure to the speakers } \\
\text { for speeding up the speaking rate and limits the } \\
\text { speakers to add other new items. The major } \\
\text { effect on learning is repetition. }\end{array}$
\end{tabular}
however, in order to present detailed findings, a target number of learners need to be followed; to require a class sitting with face-to-face communication (see Appendix A);

There are a total of three rounds for a speaker to talk repetitively at a decreased time from 4 minutes at the first round, to 3 minutes in the middle and 2 minutes for the last round. To require a time keeper to count minutes in class;

The speakers repeats the same talk, but with a reduced duration of time;

Through pair work: one is listener and the other is speaker, once finished, quickly switching the role in each round;

Nation (1997) suggested giving too much attention on language items will make learner feel fear to make mistakes and slow down the rate of speaking. Errors can be explored by learner themselves if they make. This is encouraged students to learn from errors.

The EFL learners should be familiar with the target language items, topics and content. These EFL learners can control them easily because fluency activity does not require learning new language items; in addition, it is best if EFL learners can choose the topic that is actually happened in their life (Brown \& Nation 2007).

No interruption during the whole task, i.e. listener is not allowed to ask any question to the speaker;

The speaker always has a different audience each time and the attention for the speaker is to focus on meaning and communicative message.

\subsection{Checklist}

In order to ensure the 4/3/2 activity is implemented in a correct way, the EFL teachers should be confident with their understandings of the guidelines. That to identify the conditions whether it is a good time to develop speaking fluency in their class is a first consideration. They are also strongly recommended to set up a checklist before, during and after doing this task. Generally speaking, the EFL teachers should be able to establish the class sittings; to provide the clear instructions to their students who are required to obey the 4/3/2 rules, which is an important factor to precede an accurate outcome; to monitor the speaking session is well-controlled, for example whether L1 is used or not; to discover the willingness of participation; to keep the records on speaking speed improvement and to write down the notes about the errors and mistakes; to check the difficulties and 
pauses in the speaking sessions; to nominate the time keeper; to remind himself or herself about the confidential use of the tape recordings; and to provide feedbacks to the students after the task.

\subsection{Results}

The results of running the 4/3/2 activity are similar with the previous studies. To recall Arevart and Nation's (1991) findings: speaking fluency is a trainable skill and the fluency is developed by the retrieval strategy through the meaning-focused context in a long term. Figures in Appendix B and C clearly illustrate the two achievements: the increase in speaking speed and the reduction of pauses in talking and fluency achievement in class maintains the conversation in English corner in the campus. Similarly, Tam (1997) had successfully applied the 4/3/2 technique in a speaking class for a group of 16 Chinese students who study in different universities in Singapore with such positive effects. However, all these results are driven from subjective analysis with a qualitative method, which focuses on a small target group for observation. Wiersma (2000) argued the qualitative research with the interpretivism aim is for a holistic and context specific understanding of the social phenomena. Therefore, it determines the interpretivism research's result is limited in a particular area or group. This observation with eleven tertiary students may not be applicable to the other cases, for example, the EFL learners at a secondary school or the other tertiary students in the developed regions. The relevance of this study is, therefore, independent by different cases.

\section{Quantitative Data Collection and Further Interpretation}

\subsection{Design}

Since interpretivism gives up the scientific procedures and it is lack of proof process. This article further uses a quantitative method to prove the speaking fluency improved in the 4/3/2 activity will be beneficial for the authentic conversations outside the class with similar languages and contents. The evaluation of grammar structure, pronunciation, content and knowledge, comprehension, fluency and confidence of speaking, is available in Appendix D. It requires the observed figures evaluated by both teacher and students twice, before joining the 4/3/2 activity and after finishing it in the end of semester. Creswell (2003) stated that a research design with a quantitative approach is able to compare the data before and after the participation more objectively.

\subsection{Data Collections}

Each obverted question ranked a score from 1 (lowest) to 5 (highest) and six questions with a total out of 30 before doing this research. So did the ranks after the research. These questions are closely examining the key issue that the speaking fluency achievement in the EFL class will support the real conversations that require similar languages and contents. This is tested through the null hypothesis there is no difference of the speaking fluency before and after the 4/3/2 activity in one term practice, or the speaking fluency is better in previous. Whereas, the alternative hypothesis is the speaking fluency achievement in the 4/3/2 activity is better after three months. Figures are derived from Appendix C:

\begin{tabular}{|l|l|l|l|}
\hline Time & N - Sample Number & Sample Mean(out of 5) & SD of the Sample \\
\hline Pre research & 11 & 2.09 & 0.48 \\
\hline Post research (3 months later) & 11 & 2.41 & 0.69 \\
\hline
\end{tabular}

6.3 Data Analysis: to process a paired t-test at 5\%, 2.5\% and $1 \%$.

Done a paired t-test on comparing the data before and after the development of 4/3/2 activity, the $t$ value observed 2.806 with 3 decimal places, which is larger than 1.812 (DF 10 \& rejected region 5.0\%), and 2.228 (DF $10 \&$ rejected region $2.5 \%$ ) and also greater than 2.764 (DF $10 \&$ rejected region $1.0 \%$ ). It is obviously that the 
Yang, Y.

null hypothesis is rejected and the alternative hypothesis is valid in this case.

\subsection{Findings}

The first finding is that the overall proficiency is increased especially the speaking fluency and the confidence of speaking. Secondly, most EFL learners' grammar structure is improved after this research period. However, two students' grammar accuracy decreased because they speed up dramatically when speaking with sacrificing meaning. Furthermore, this research also shows that there is an increase of motivation in practicing speaking fluency. The willingness of participating in public speaking is high. The standard deviation before and after the research is enlarging, which indicates some EFL learners improving fast and others may make their progress slowly. The major finding in continuing doing the 4/3/2 activity that the EFL learners' improvement in speaking fluency in class is eventually supporting the real conversations that require similar languages and contents.

\subsection{Ethics}

The participants in this proposed research are the collaborators. It is important to consider the ethics and politics issues as Gay et al. (2006) described as "built on trust between the researcher and participants". Participants' motivation, confidence and willingness will directly decide the reliability and validity of results. Both the researcher and participants had established a good and close relationship. However, to ensure such activity is under the university and education policy. A declaration statement with the intended audiences for the research purpose is required to sign up and to get permission from the participants for tape recording in observation. The usage of tape recording is only for researching purpose; meanwhile, their results are listed by the initials of the family and first names.

\section{Discussion and Conclusion}

\subsection{Discussion}

First of all, the significance of this research is the anticipated uses in the communicative language teaching. It provides a clear picture why and how to use 4/3/2 activity in EFL class. The 4/3/2 activity is cheap with little costs, but a powerful technique because all the EFL students have opportunities to be involved in. The guideline and condition are the key to apply the 4/3/2 activity and the checklist is for the EFL teacher to prepare and manage it more sufficiently. The total duration is 18 minutes, which occupies less than one third of a one hour lesson. After demonstrating the 4/3/2 activity, it is warmly welcome by the EFL students. The 4/3/2 activity is a typical fluency technique to switch the traditional teaching model into the communicative language teaching model. So, there is no reason to reject it if practicing speaking fluency in the EFL class.

Second, the EFL teachers need to understand that the learning situation in China. In the year 2007, the researcher did a survey for a 50-student EFL class: the 4/3/2 activity is not familiar to students at all; only $26 \%$ students in class realized the importance of fluency; around $10 \%$ of them enjoyed the EFL class; and less than $5 \%$ think they are able to communicate to a native speaker. Jin (2006) pointed out most EFL students learn vocabulary through memorizing and practice their listening and reading skills through the context silently. This totally ignores the meaning-focused output and fluency development strands. EFL teachers should check whether the 4/3/2 activity is suitable for anticipated uses in their class. Survey and interview could be a good way to understand student's needs. A good preparation is the beginning of success.

Third, the findings in the development of speaking fluency are positive in many aspects. The time is very efficient as an 18 minutes session covers speaking practice for all students. The participation rate is high according to the record in the research. Students enjoy the activity and their willingness of participation in the English corner is also increasing. Brown (2007) stated motivation is yet an affective variable to be considered in 
the language teaching and learning. The motivation increases in learning will enhance the language knowledge used repetitively outside the class. Ur (1996) argued speaking is the most important skill in learning a foreign language. The large demand of speaking skill creates such opportunity to improve speaking fluency. Thanesh (2013) explores there is a shift focusing on fluency development in India now. As a consequence, the attention should be paid on meaning-focused output and fluency development strands for the communicative competence.

Next, this proposed study neither seeks for any quantitative data to explore the nature of fluency, nor judges the proficiency of the EFL learners, but attempts to evaluate the progress and achievement in order to prove that the speaking fluency development is possible to be achieved. From interpreting the qualitative data, Yin (2009) mentioned one very important condition is to control the researcher is more important than the actual behavioral events when designing a case study. It is obvious that case study has both advantages and disadvantages and one weakness is that it is not possible to collect all statistical data for the whole population. That is why its application is in a limited area. Quantitative method is a scientific approaching supported by figures. It fills a gap that qualitative method cannot perform. Complementary, quantitative data finally proved that realiability and validity of the $4 / 3 / 2$ activity can effect on the real conversation. This is an attempt to combine both the qualitative and quantitative methods with complementary contribution.

Fifth, the implication of doing this research consists of patience, confidence and motivation in a long period of time. These factors need to be aware of in order to explore an authentic achievement in speaking fluency development. Hine (2000) listed nine observational dimensions in research and one is participants' emotional feeling during and after the observation. This offers learners a comparison for their achievements. The more advantages gained in the observation, the more confidence of using the language is in the near future. The EFL teacher needs to create opportunities for the learners to develop fluency and speaking the language in real communication at a maximum rate. Here are some advices and tips: a) meaning-focused is also learning and learning a language is for using it in life; b) do not hesitate to learn new language items and contents; try to be familiar with them and fluently use them; c) do not be embarrassed when audience points out errors; d) never give up because learning from mistakes; e) confidence is a key to be successful in language learning; f) the retrieval strategy is to use what you learnt and known, to practice, practice, practice, and practice makes perfect.

\subsection{Conclusion}

This research provides a strong reason for implementing the communicative language teaching in the EFL class in China. The 4/3/2 activity fills a gap between developing speaking skills and speaking fluency. The discussion of the importance of fluency, the procedure of running the 4/3/2 activity and the practice of speaking fluency in the long term, are all included. The three questions are answered by both qualitative and quantitative approaches. It not only proves the authenticity in previous studies: fluency is a trainable skill through increasing the speaking words per minute and reducing the pauses in speaking, but also explores the practice of speaking fluency is simultaneously increasing the accuracy of grammar through meaning-focused production. Therefore, the 4/3/2 activity is not conflict with the goal of grammar-translation method. The development of speaking fluency through communicative language learning either links the EFL learners' motivation and the opportunity of speaking. Learning in class is for the purpose of using in life. The speaking fluency development is a way of best using the known content and knowledge, hence the EFL teachers may ask their students to write down the content that they talked in the 4/3/2 activity after class for homework. This is a post task to review the performance again and repetition is at a fourth time. The EFL learners will not find writing is so difficult in this situation. In a long term, the speaking fluency achievement in the practice in class will be beneficial for the real-life conversation that requires the similar languages and contents.

\section{References}

An, X., \& Wang, D. (2013). Bilingual education in the context of China: A review and its implication. Sino-US English Teaching, 10(2), 131-136. 
Yang, Y.

Arevart, S., \& Nation, I.S.P. (1991). Fluency improvement in a second language. RELC Journal, 22(1), 84-94. http://dx.doi.org/10.1177/003368829102200106

Brown, H.D. (2007). Principles of language learning and teaching (5th ed.). New York: Pearson Longman.

Bresnihan, B., \& Stoops, B. (1996). Three ways that work! Oral fluency practice in the EFL classroom. English Teaching Forum, 34(3), 30.

Brown, S., \& Nation, I.S.P. (1997) Teaching speaking: suggestions for the classroom. The Language Teacher, 21(1), 11-18.

Brumfit, C. (1984). Communicative methodology in language teaching: The roles of fluency and accuracy. Cambridge: Cambridge University Press.

Chambers, F. (1997). What do we mean by fluency? System, 25, 535-544. http://dx.doi.org/10.1016/S0346-251X(97)00046-8

Creswell, J. W. (2003). Research design: Qualitative, quantitative, and mixed methods approaches $\left(2^{\text {nd }}\right.$ ed.). Thousand Oaks, CA: Sage.

Dai, W. (2007). Opportunities and challenges of foreign language teaching. Shanghai: Foreign Language Teaching Press.

Ejzenberg, R. (2000). The juggling act of oral fluency: A psycho-sociolinguistic metaphor. In H. Riggenbach (Eds.), Perspectives on fluency (pp. 287-314). Michigan: The University of Michigan Press.

Fillmore, C. J. (1979). On fluency. In D. Kempler \& W. S. Y. Wang (Eds.), Individual differences in language ability and language behavior (pp. 85-102). New York: Academic Press.

Freed, B. (1995). What makes us think that students who study abroad become fluent? In B.Freed (Ed.), Second language acquisition in a study abroad context (pp. 123-148). Amsterdam: John Benjamins.

Gai, Y. (2004). Socio-psychology of English learning by Chinese university students. Beijing: Foreign Language Teaching and Research Press.

Gardner, R. C. (1985). Social psychology and second language learning: The role of attitude and motivation. London: Edward Arnold.

Gay, L.R., Mills, G.E., \& Airasian, P. (2006). Educational research: Competencies for analysis and applications ( $8^{\text {th }}$ ed.). Upper Saddle River, New Jersey: Pearson Education Ltd.

Geertz, C. (1973). The interpretation of culture. New York: Basic Books.

Hartmann, R. R. K., \& Stork, F. C. (1976). Dictionary of language and linguistics. New York: Wiley.

Hine, C. (2000). Virtual ethnography. London: Sage.

Jin, Y. (2006). The improvement of the test validity and its backwash effects. Foreign Language World, 6, 65-73.

Kachru, B. (1992). World Englishes: approaches, issues and resources. Language Teaching, 25, 1-14. http://dx.doi.org/10.1017/S0261444800006583

Kopenen, M., \& Riggenbach, H. (2000). Overview: Varying perspectives on fluency. In H. Riggenbach (Eds.). Perspectives on fluency (pp. 5-24). Ann Arbor, MI: The University of Michigan Press.

Lennon, P. (1990). Investigating fluency in EFL: A quantitative approach. Language Learning, 40, 387-412. http://dx.doi.org/10.1111/j.1467-1770.1990.tb00669.x

Lennon, P. (2000). The lexical element in spoken second language fluency. In H. Riggenbach (Eds.), Perspectives on fluency (pp. 25-42). Ann Arbor, MI: The University of Michigan Press.

Maurice, K. (1983). The fluency workshop. TESOL Newsletter, 17(4), 29.

Nation, I.S.P. (1989). Improving speaking fluency. System, 17(3), 377-384. http://dx.doi.org/10.1016/0346-251X(89)90010-9

Nation, I.S.P. (1991). Fluency and learning. The English Teacher, 20, 1-8.

Nation, I.S.P. (1997). Developing fluency in language use. KIFL Academic Journal, 6, 30-35.

Nation, I.S.P. (2007). The four strands. Innovation in Language Learning and Teaching 1(1), 1-12. http://dx.doi.org/10.2167/illt039.0

Nunan, D. (2003). The impact of English language as a global language on educational policies and practices in the Asia-Pacific region. TESOL Quanterly, 37(4), 589-613. http://dx.doi.org/10.2307/3588214

Porter, P., \& Grant, M. (1992). Communicating effectively in English: Oral communication for non-native speakers. Belmont: Wadsworth Publishing Company. 
Richards, J., \& Rodgers, T. (2001). Language and methods in language teaching. Cambridge: Cambridge University Press.

Riggenbach, H. (1991). Towards an understanding of fluency: A microanalysis of nonnative speaker conversation. Discourse Processes, 14, 423-441. http://dx.doi.org/10.1080/01638539109544795

Schloff, L., \& Yudkin, M. (1991). Smart speaking: Sixty-second strategies. New York: Henry Holt and Company.

Schneider, P. (2001). Pair taping: Increasing motivation and achievement with a fluency practice. TESL-EJ, 5 (2). Retrieved from http://www-writing.berkeley.edu/TESLEJ/ej18/a2.html

Scotland, J. (2012). Exploring the philosophical underpinnings of research: Relating ontology and epistemology to the methodology and methods of the scientific, interpretive, and critical research paradigms. English Language Teaching, 9(5), 1-16.

Tam, M. (1997). Building fluency: A course for non-native speakers of English. English Teaching Forum, 35(1), 26.

Thanesh, U. (2013). Testing oral skills: An innovative approach to promote fluency. Language in India, 13(3), 381-390.

Towell, R. (1987). Variability and progress in the language development of advanced learners of a foreign language. In R. Ellis (Eds.), Second language acquisition in context (pp. 113-127). Toronto: Prentice Hall.

Ur, P. (1996). A course in language teaching: Practice \& theory. Cambridge: Cambridge University Press. Wiersma, W. (2000). Research methods in education: An introduction (7th ed.). Boston: Allyn \& Bacon.

Wood, D. (2001). In search of fluency: What is it and how can we teach it? Canadian Modern Language Review, 57(4), 573-589. http://dx.doi.org/10.3138/cmlr.57.4.573

Yin, R. K. (2009). Case study research: Design and methods (4th ed.). Thousand Oaks, California: Sage Publications. 
Yang, Y.

\section{Appendix A}

Suggested class settings

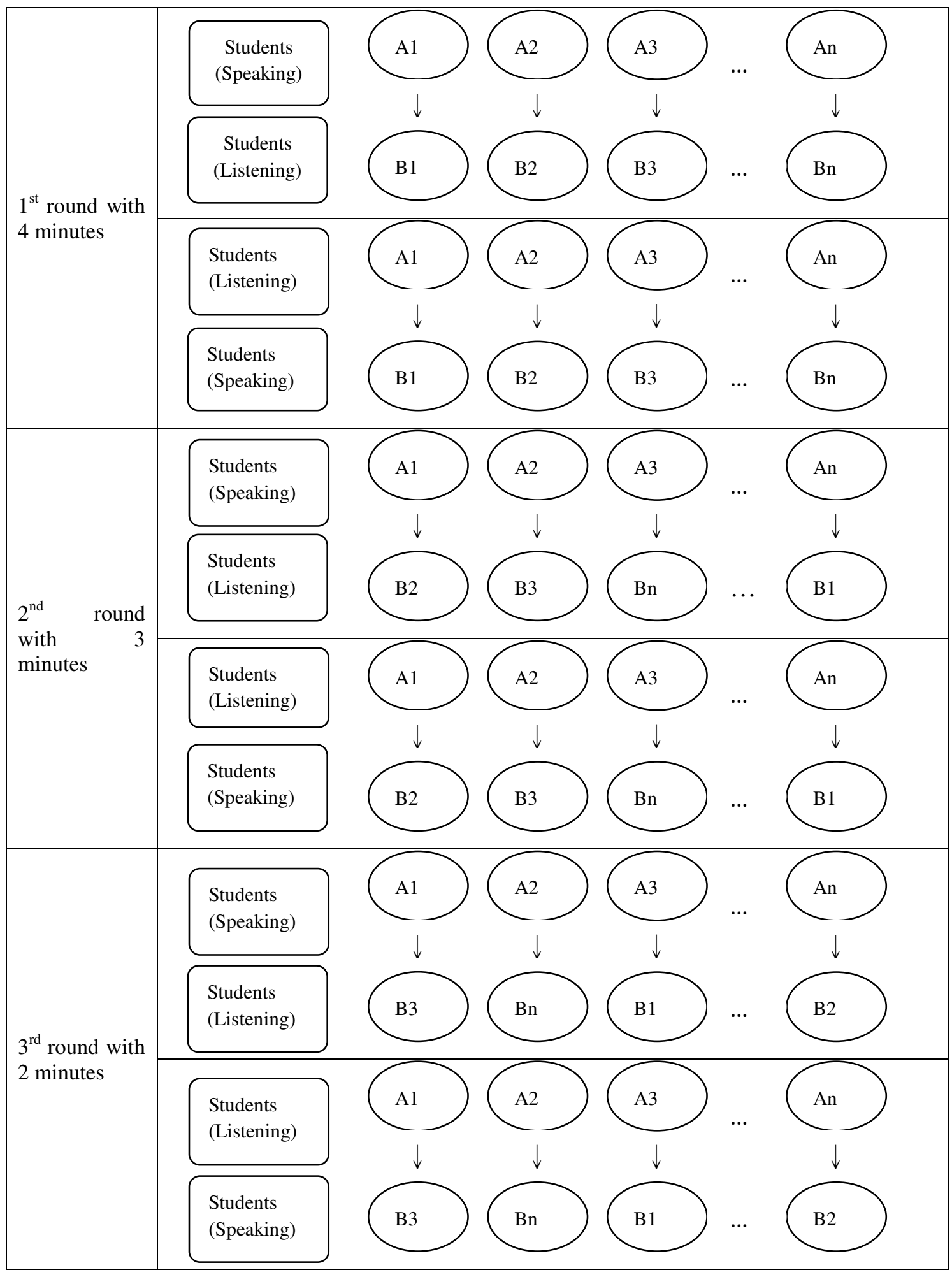




\section{Appendix B}

\begin{tabular}{|l|l|l|l|}
\hline & Subject/topic & $\begin{array}{l}\% \text { increase words per minute } \\
\text { (from } 1^{\text {st }} \text { to } 3^{\text {rd }} \text { delivery) }\end{array}$ & $\begin{array}{l}\% \text { decrease pauses in } 100 \text { words } \\
\text { (from } 1^{\text {st }} \text { to } 3^{\text {rd }} \text { delivery) }\end{array}$ \\
\hline 1 & Travel to a place & $15.60 \%$ & $18.70 \%$ \\
\hline 2 & Transportation & $11.60 \%$ & $10.40 \%$ \\
\hline 3 & Weather in your city & $18.30 \%$ & $11.50 \%$ \\
\hline 5 & Sports and competition & $7.50 \%$ & $6.80 \%$ \\
\hline 6 & Study at university & $33.80 \%$ & $37.70 \%$ \\
\hline 7 & Yout family & $13.70 \%$ & $17.60 \%$ \\
\hline 8 & How to find a job & $12.90 \%$ & $15.20 \%$ \\
\hline 9 & Shopping & $22.60 \%$ & $21.30 \%$ \\
\hline 10 & Your best friend & $6.60 \%$ & $11.70 \%$ \\
\hline 11 & Dreams in your life & $21.60 \%$ & $16.30 \%$ \\
\hline 12 & Future plan & $9.80 \%$ & $13.10 \%$ \\
\hline & Average & $14.30 \%$ & $17.70 \%$ \\
\hline
\end{tabular}


Yang, Y.

\section{Appendix C}

\begin{tabular}{|l|l|l|l|l|l|l|l|}
\hline Students & Q1 & Q2 & Q3 & Q4 & Q5 & Q6 & Overall before \\
\hline 1 XY & 2 & 2 & 2 & 2 & 1 & 1 & 1.67 \\
\hline 2 ZC & 2 & 2 & 1 & 2 & 1 & 1 & 1.50 \\
\hline 3 XYF & 2 & 2 & 2 & 2 & 1 & 2 & 1.83 \\
\hline 4 ZJX & 4 & 3 & 2 & 2 & 2 & 2 & 2.50 \\
\hline $5 \mathrm{WF}$ & 2 & 2 & 2 & 1 & 1 & 1 & 1.50 \\
\hline $6 \mathrm{WWY}$ & 3 & 3 & 3 & 2 & 3 & 3 & 2.83 \\
\hline $7 \mathrm{TLP}$ & 2 & 3 & 2 & 3 & 2 & 2 & 2.33 \\
\hline $8 \mathrm{ZY}$ & 3 & 2 & 2 & 2 & 2 & 2 & 2.17 \\
\hline 9 ZP & 2 & 2 & 2 & 2 & 1 & 1 & 1.67 \\
\hline $10 \mathrm{CHH}$ & 3 & 2 & 3 & 2 & 2 & 2 & 2.33 \\
\hline $11 \mathrm{WJW}$ & 3 & 2 & 3 & 2 & 3 & 3 & 2.67 \\
\hline
\end{tabular}

\begin{tabular}{|l|l|l|l|l|l|l|l|}
\hline Students & Q1 & Q2 & Q3 & Q4 & Q5 & Q6 & Overall after \\
\hline 1 XY & 3 & 3 & 2 & 2 & 2 & 2 & 2.33 \\
\hline 2 ZC & 2 & 2 & 2 & 2 & 2 & 1 & 1.83 \\
\hline 3 XYF & 3 & 2 & 2 & 3 & 2 & 3 & 2.50 \\
\hline 4 ZJX & 3 & 3 & 3 & 3 & 3 & 2 & 2.83 \\
\hline 5 WF & 2 & 2 & 1 & 2 & 1 & 2 & 1.67 \\
\hline 6 WWY & 4 & 3 & 3 & 3 & 4 & 4 & 3.50 \\
\hline 7 TLP & 3 & 2 & 2 & 3 & 3 & 2 & 2.50 \\
\hline 8 ZY & 2 & 2 & 2 & 1 & 2 & 2 & 1.83 \\
\hline 9 ZP & 2 & 2 & 1 & 1 & 1 & 1 & 1.33 \\
\hline $10 \mathrm{CHH}$ & 4 & 2 & 3 & 2 & 3 & 3 & 2.83 \\
\hline $11 \mathrm{WJW}$ & 4 & 3 & 3 & 3 & 3 & 4 & 3.33 \\
\hline
\end{tabular}




\section{Appendix D}

\section{An evaluation of the proficiency level}

Question 1-Grammar Structure

$\square$ - the use of grammar accuracy is close to a native speaker

$\square$ 4- the grammar structure is quite clear with few errors

$\square$ 3- occasional errors, but able to maintain the conversation easily

$\square$ 2- the grammar structure is acceptable but with some ambiguous structures

1- only have very basic grammar knowledge and process very simple structure of sentence

Question 2-Pronunciation

5- the pronunciation is close to a native speaker

4- the articulation of content is mostly understood by the audiences

3- to clearly and coherently pronounce the words and collocations

$\square$ 2- some accent, the pronunciation is understood by the same ethnic members

$\square$ 1- strong accent, it is difficult for others to understand

Question 3 - Content and Knowledge,

5 - is able to talk with the native speaker sufficiently

4- intelligibly to be participated in the in social communicates

3- be able to involve in the daily conversations

2- only for very basic information exchange, for example, the survival communication

1- the communication with English content and knowledge is impossible

Question 4 - Comprehension

5- to understand the conversation easily like a native speaker

$\square$ 4- be able to catch and interpret most of the comprehension

$\square$ 3- struggling with the comprehension, follow up the content with careful concentration

$\square$ 2- only understand very simple and slow sentences

1- failed to understand the content

Question 5 - Fluency

5- speaking very fluently like a native speaker

4- speaking with little pauses and hesitations

3- speaking with some hesitations, not struggling but self-motivated 
Yang, Y.

$\square$ 2- speaking slowly and unable to make long sentences because recall words and grammar structure

$\square$ 1- lack of fluency development: Only speaking with single words and short expressions

Question 6 - Confidence of Speaking

5- very confident to speak in public

$\square$ 4- to attempt in many speaking activities in class

$\square$ 3- a little fear about the error making, but put effort in speaking

$\square 2$ - try to speak and produce meaning, but worried to make mistakes

$\square 1$ - is not willing to speaking in class 